\title{
Can Increased Trade Prevent Conflict With China?
}

Stephen Rush, Amica Mutual Insurance, USA

Sam Mirmirani, PhD, Bryant University, USA

\begin{abstract}
China is a salient subject in U.S. trade policy debates as a result of its growing world influence and national interests that sometimes conflict with those of the United States. Often the focus on a sustainable current account deficit and the impact of increased financial integration is overlooked in favor of more emotional issues such as Chinese labor conditions and the loss of U.S. manufacturing jobs. This paper explores the increasing current account deficit with China, its impact on the Dollar, and the effects of integration on economic growth.
\end{abstract}

Keywords: China, Trade, Deficit, Integration, Currency, Dollar, Yuan

\section{INTRODUCTION}

¿ n the early 1990s, the United States began to run a significant trade deficit with China due to the dual forces of greater trade liberalization and China's transition from a command economy towards a market economy. Proponents of free trade with China argue that greater integration will lead to a convergence of interests that reaches beyond economics. Despite growing economic and cultural ties with China, the U.S. still maintains military assets to defend Taiwan. Large scale conflicts on the order of cold war expectations are unlikely due to the growing importance of multinational entities such as international institutions, corporations, and nonprofits. This means that developed nations must contend with world opinion or forego the assistance of these groups in pursuing national interests. Situations such as Taiwan could limit economic integration and potentially introduce long term political risk with an impact on the U.S. economy similar to the Middle East effect on oil price.

While the Chinese government presents itself as a monolithic entity to foreigners, the ability of the central government to enforce policy differs greatly throughout the country. The potential for political instability will likely increase as China becomes more integrated with the rest of the world. Western nations have already experienced the challenges of applying World Trade Organization regulations on market driven economies. The effects will be even more difficult to manage in China's hybrid economy. The Chinese government's primary concern is to govern the entire nation with diverse cultures, languages, and economic interests despite a lack of infrastructure and strong institutional development. To do this without some form of participatory government requires a population which is not critical of government policies. This is achieved through the promise of economic growth.

The first section of the paper will review the current literature on financial integration and trade liberalization. Many analysts have commented on China's increasing foreign reserves. The US trade deficit with China is primarily financed through the sale of US treasury bonds and the Chinese central bank is one of the largest buyers of these securities. A substantial decrease in the demand for these securities could lead to a dramatic increase in the US interest rate. While China may not reduce the amount of Dollars purchased, the use of these reserves is also controversial. China's accumulation of Dollars has been used to secure resources in Africa and oil in the Middle East. While China's leaders may be inclined to keep large currency reserves to support future exchange rate policy, there remains an increasing amount of Dollars which cannot be spent. This Dollar surplus is a potential threat to world economic stability.

The second section will describe the current trade relationship and the challenges ahead. In addition to the trade deficit and the exchange rate, the U.S. has recently imposed countervailing tariffs on glossy paper products to 
offset subsidies provided by the Chinese government. The terms of China's accession to the WTO have been difficult to implement due to both caution on the part of the Chinese government and the ability of the government to enforce policy. Over the past several months, the U.S. has adopted a tougher stance on Chinese trade conflicts largely as a response of the Bush administration to a democratic congress rather than a change in American trade policy.

Previous incidents have introduced temporary volatility into American financial markets, but could China introduce sustained volatility? If so, what would be the long term impact of sustained market volatility to the U.S. economy? The third section will explain the degree to which the U.S.-China trade relationship can introduce volatility in the U.S. markets and explain its long term effects. The U.S. attracts large amounts of foreign portfolio investment based on the relatively low risk and efficiency of American markets. A lack of capital controls combined with America's dependence on foreign capital could cause a significant decrease in investment if the market were perceived to be too risky when compared to the rate of return. While capital flight on the scale of the Asian financial crisis is unlikely, any substantial loss of foreign investment could significantly impact American economic growth.

The long term impact of a sustained current account deficit must be considered in terms of the valuation and portfolio balance effects. The relationship between the current account, exchange rate, and the national debt will be examined in order to determine the amount of a sustainable current account deficit. The conclusion will place the U.S.-China trade deficit in perspective with a brief description of the Gulf Cooperation Council's relationship with the U.S. This section will also describe the U.S. policies necessary to prepare for a stronger Chinese economy with a floating exchange rate.

\section{LITERATURE REVIEW}

Since the 1980's, the U.S. has run a current account deficit much of which can be attributed to the trade relationship with China. There are generally two perspectives from which to view the situation. The pessimistic view holds that Americans are living beyond their means by borrowing from other countries in order to fund consumption and investment which exceeds domestic savings. The optimistic view is that U.S. markets attract more foreign capital because of a more competitive risk to return ratio. In either case, the real question is sustainability. Sumner defines the current account deficit as being sustainable if "neither it, nor the associated foreign capital inflows, nor the negative international investment position are large enough to induce significant change in economic variables such as, consumption or investment or interest rates or exchange rates."

If the current account deficit is large enough, interest payments will affect consumer spending and investment thereby reducing GDP growth potential. According to Mann (2002), a higher initial long term growth rate will allow the current account deficit to persist longer before affecting future growth. "For industrial countries, a ratio of current account deficit to GDP of somewhere between 4 and 5 percent appears to be associated with the onset of economic forces that reduce consumption and particularly investment and change the trajectory of the current account and return it to sustainable territory." ${ }^{3}$ Mann also qualifies this statement by conceding that a comparison of the U.S. to other industrial countries may not be accurate due to the amount of foreign-purchased U.S. assets. In other words, the U.S. is able to attract much more foreign capital than other nations because of exogenous factors such as reduced risk in the form of the regulatory and legal environment.

A loss of confidence in the Dollar can cause investors to react in two ways: demand a risk premium on U.S. securities or downgrade long term real exchange rate equilibrium estimates. If investors wanted to move their money out of the U.S., Krugman (1989) says that the result will be a fall in price with few actual sales. This means that the weakening of the Dollar is the first sign of investors' loss of confidence in the Dollar, not capital flight. On the other hand, a small Dollar depreciation is not cause for alarm. In the short term, a decline in the Dollar does not affect the current account because trade flows take years to respond to exchange rates. ${ }^{4}$

\footnotetext{
${ }^{1}$ Mann, 134

${ }^{2}$ Mann, 143

${ }^{3}$ Mann, 144

${ }^{4}$ Krugman, 32-33
} 
The weakening Dollar hurts the U.S. because foreigners are able to buy up American assets rather than simply causing American goods to become more competitive. This explains the downside of the J-curve. If trade flows adjusted quickly to exchange rates, U.S. assets would increase in price to make up for higher demand causing the Dollar to appreciate. Trade flows take several years to adjust to exchange rate changes due to setup costs and sourcing contracts as opposed to the trade in financial assets which can take seconds. This results in capital flows being more responsive to the exchange rate than the current account.

Kraay and Ventura (2002) showed that trade integration defined as the movement of goods from having prohibitively high transportation costs to negligible transportation costs increases the volatility of a country's trade balance. Trade integration limits the movement of the terms of trade mitigating the stabilizing effect on the trade balance. This means that both supply and demand shocks have greater effect on the economy. ${ }^{5}$

Supply side shocks affect the economy differently depending on the level of trade integration. With less integration "...shocks that raise labor productivity primarily raise the production of goods already produced in the country, and this lowers their prices and worsens the terms of trade... Similarly, shocks that lower labor productivity improve the terms of trade, moderating the resulting trade deficit." ${ }^{\prime 6}$ On the demand side, transportation costs cause a preference for domestic goods. Shocks which increase spending improve the terms of trade while negative shocks worsen the terms of trade because consumers' preferences cause a greater change in spending on domestic goods than foreign goods.

There are two instances in which trade integration will not cause greater volatility. The first is that newly traded goods benefit much more from comparative advantage than previously traded goods. This situation is unlikely because high transportation costs encourage trade in goods with the greatest comparative advantage. As transportation costs decrease, more goods with less comparative advantage will be traded. If transportation costs continue to fall, trade integration will be biased towards goods with weak comparative advantage.

The second instance is that preferences are extremely risk adverse. In this case, risk aversion is determined by the extent to which changes in the terms of trade affect spending. If changes in the terms of trade affect spending, a risk aversion coefficient greater than 1 will introduce greater volatility in the trade balance. Conversely, a risk aversion coefficient less than 1 will decrease trade balance volatility. This effect is caused by consumers' preference for domestic goods. While Kraay and Ventura do not determine the precise point at which this relationship breaks down, extreme values of the risk aversion coefficient are unlikely to occur.

Financial openness has a negative effect on the relative volatility of consumption only after gross capital flows exceed $50 \%$ of GDP. ${ }^{7}$ The traditional explanation for terms of trade instability is that the volatility is caused by commodity prices on which a country's exports depend upon. Razin (2003) presents a case for terms of trade volatility introduced by high setup costs for new investment. This model is more consistent with the U.S.- China trade relationship due to the large amount of finished and intermediate manufactured goods which account for a large portion of trade. He concludes that "...trade openness may cause either appreciation or depreciation of the setup cost of investment, through changes in the terms of trade, and thereby may generate instability in the form of boom-bust investment cycles."

Whether it is volatility from terms of trade or from the exchange rate, output volatility has a negative influence on growth. In developed countries, one standard deviation of volatility decreases per capita annual growth by one third of a percentage point. ${ }^{9}$ This situation aggravates attempts to rebalance the current account because the fiscal deficit also limits how large the current account can grow before affecting output. ${ }^{10}$ Reduced growth caused by terms of trade volatility could begin a feedback loop which would require enormous fiscal discipline to stop. The

\footnotetext{
${ }^{5}$ Kraay and Ventura, 1024

${ }^{6}$ Kraay and Ventura, 1024

${ }^{7}$ Kose et al, 136

${ }^{8}$ Razin, 286

${ }^{9}$ Ramey and Ramey, 1141

${ }^{10}$ Blanchard et al., 21
} 
Brookings Institute paper concludes that the U.S. current account deficit is so unprecedented that future effects cannot be accurately predicted from historical data. ${ }^{11}$

\section{CURRENT TRADE RELATIONSHIP}

China's real annual GDP growth has averaged about $10 \%$ for the past four years and today it ranks as the second largest economy in terms of purchasing power parity. While private consumption accounts for only $38 \%$ of GDP, China's sustained high growth rate has been fueled by exports rather than domestic consumption. As such, China's current account balance has increased by about 578\% since 2002. Despite this level of sustained growth, inflation has remained under control and is currently at $2.7 \% .{ }^{12}$ China still utilized price control particularly in the energy sector which artificially limits inflation however, the government is slowly moving towards a market economy and price controls are likely to be short lived. The Chinese currency goes by two names depending on its usage. The Yuan is often used to describe the value of the entire currency whereas renminbi, the People's Currency abbreviated RMB, is used when discussing a price.

In 1980, the U.S. and China provided mutual most favored nation treatment in order to strengthen the diplomatic relationship established in $1979 .{ }^{13}$ This agreement stipulates that each country must extend the same trade agreements to each other as they extend to their most favored trading partner. After a brief surge in U.S. exports, the trade balance began falling at an increasing rate. This has been a cause of concern as it relates to the growing net debt position of the U.S. and the exchange rate between the Yuan and Dollar. Disagreements over China's WTO responsibilities exacerbate these problems by causing many people to call for protectionist measures such as tariffs and quotas in order to respond to what is perceived as unfair trade practices.

As of 2005, China is the United States' third largest trading partner behind Canada and Mexico and is second only to Canada as a source of imports. ${ }^{14}$ China has a fixed exchange rate in which the Yuan is widely regarded as being undervalued relative to the Dollar. This causes Chinese exports to be more competitive than U.S. goods resulting in a current account deficit. The trade deficit has been blamed for the loss of consumer goods manufacturing jobs in the U.S. because many U.S. firms cannot reduce labor costs enough to make a profit while setting a competitive price for their goods. Many Chinese businesses are wholly or partially state owned. This also causes concern for policy makers when government owned firms purchase U.S. firms in strategic industries.

\section{Trade Deficit}

According to the Bureau of Economic Analysis, the U.S. exported 55.224 billion Dollars worth of goods and services to China over 2006. Over the same period, the U.S. imported 287.772 billion Dollars worth of goods and services for a trade deficit of 232.548 billion. In order to compensate for this deficit in the current account, the U.S. must either create a trade surplus with other countries or run a capital account surplus. This effectively means that China is loaning money to the U.S. to purchase Chinese goods and services. According to Mann (2002), financial inflows compensating for the entire U.S. current account deficit amount to only $6 \%$ of world savings. ${ }^{15}$ Most of the financial account surplus from China is a result of the central bank purchasing U.S. treasury bonds. The interest payments on these bonds imply that the U.S. cannot sustain the trade imbalance indefinitely without accumulating more debt in the process.

Currently, China is the second largest buyer of U.S. treasury securities and has already amassed over one trillion in reserves. ${ }^{16}$ China's large purchase of U.S. bonds allows the U.S. to finance its debt without raising interest rates. The Economist reports that U.S. bond yields could be about 1.5 percentage points lower due to China's

\footnotetext{
${ }^{11}$ Obstfeld et al., 110

${ }^{12}$ Economist Intelligence Unit

${ }^{13}$ Morrison, 1

${ }^{14}$ Morrison, ii

${ }_{15}^{15}$ Mann, 145

${ }^{16}$ The Economist, 28 Oct 2006
} 
reserve assets. ${ }^{17}$ One of the concerns over the rising U.S. current account deficit is that foreigners will eventually reduce U.S. investment as financial markets develop in other countries which offer a higher rate of return despite the increased risk. This would place additional downward pressure on the Dollar leading to a reduction in the current account deficit which decreases capital inflows. Assuming the domestic savings rate is constant, total savings decreases with the current account deficit causing interest rates to increase.

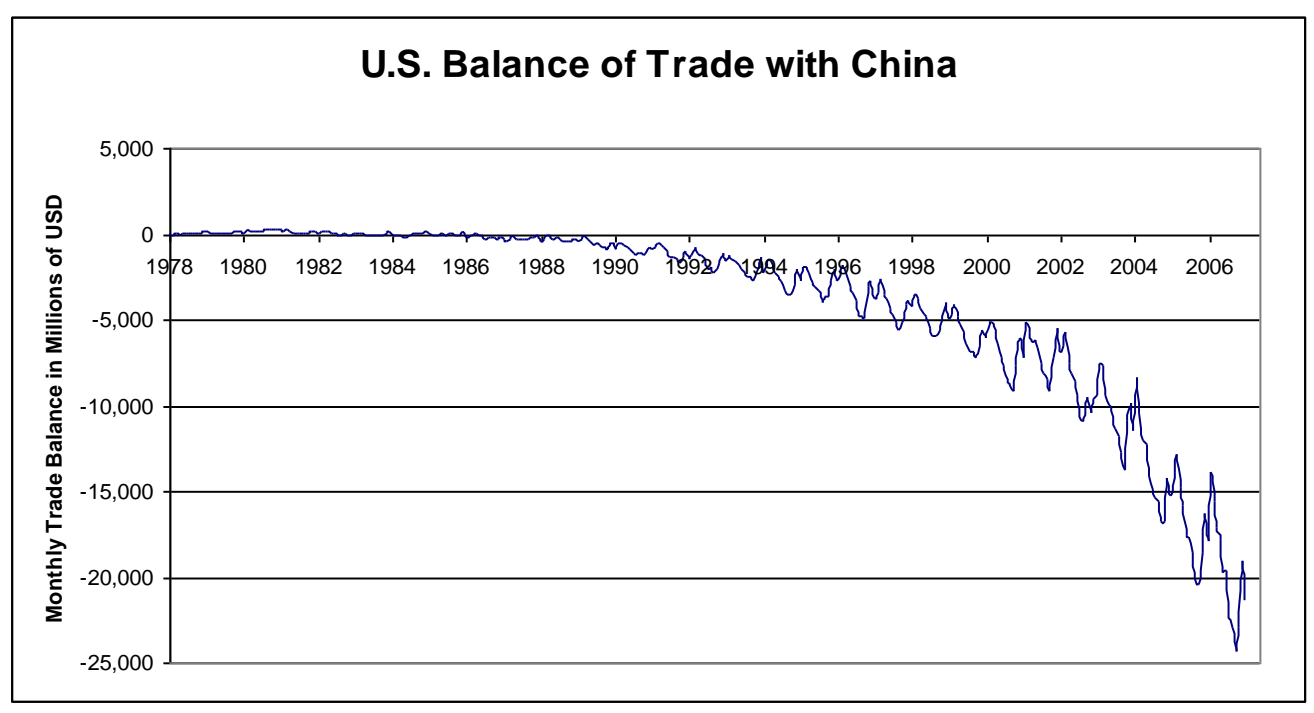

\section{Exchange Rate}

China's central bank, the People's Bank of China (PBOC), had a fixed exchange rate system pegged to the U.S. Dollar at 8.28 Yuan per Dollar up until July 21, 2005. Under international pressure, the PBOC abandoned the currency peg in favor of a managed float which is linked to a weighted basket of currencies. The result of the movement from a pegged exchange rate to a managed float was a $2.1 \%$ appreciation of the Yuan relative to the Dollar. ${ }^{18}$ Following this initial appreciation, the Yuan is only allowed to fluctuate by $0.3 \%$ relative to the Dollar on a daily basis. ${ }^{19}$ As of April 19, 2007, one Dollar is worth 7.7165 Yuan. ${ }^{20}$

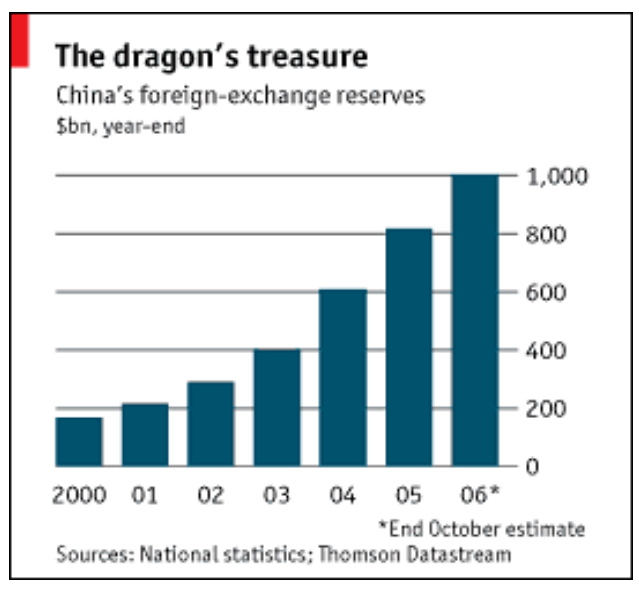

\footnotetext{
${ }^{17}$ The Economist, 28 Oct 2006

${ }^{18}$ The Economist, 22 July 2005

${ }^{19}$ Lum and Nanto, 3

${ }^{20}$ Yahoo Finance, 19 April 2007
} 
Value of the Yuan Relative to the Dollar

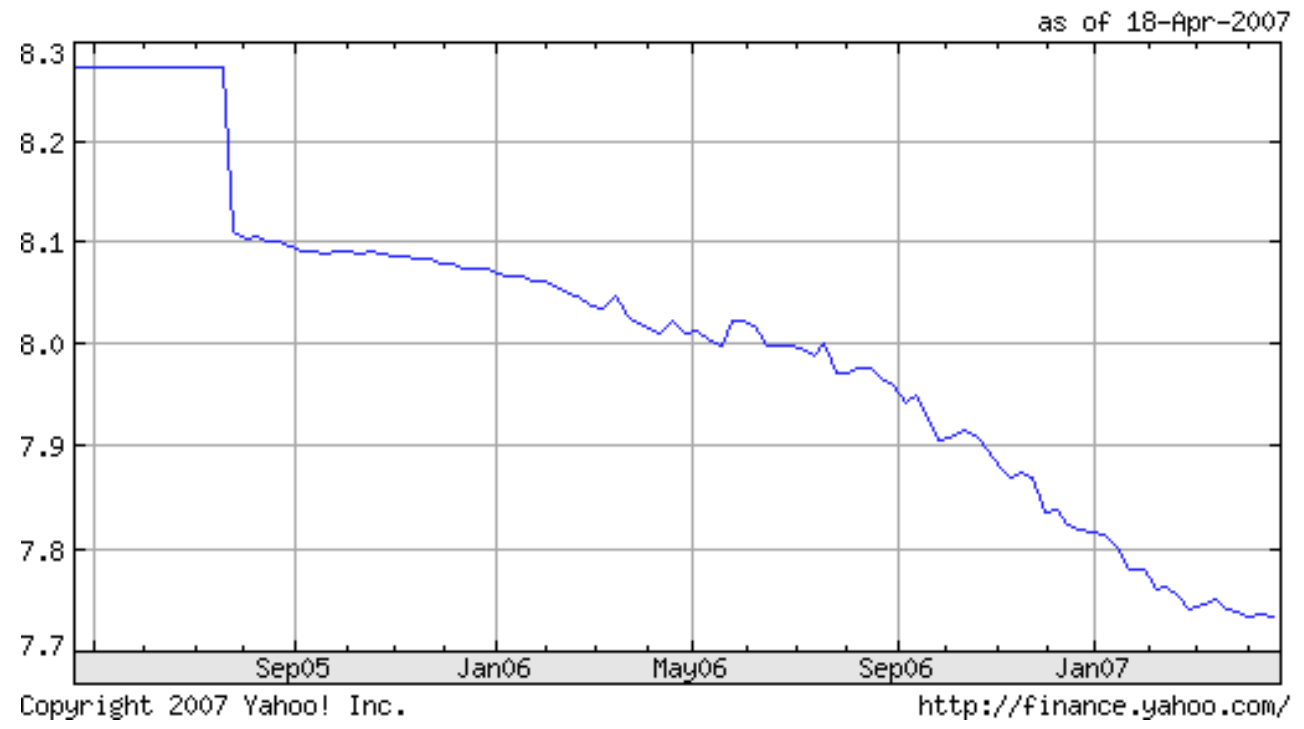

The Economist magazine maintains a group called the Economist Intelligence Unit which provides economic data to government agencies and private companies. The Economist Intelligence Unit estimates that the Yuan will continue to appreciate to 7.10 Yuan per Dollar by 2011. Since the initial revaluation in 2005, the Yuan has appreciated against the Dollar at an average rate of 0.22 Yuan per year. If this trend continues, the Yuan will appreciate to 7 Yuan/Dollar in 2010. This rate is still widely regarded as being undervalued in order to promote exports. The undervalued Yuan allows Chinese exporters to sell their goods much cheaper than their American counterparts causing many U.S. businesses to become relatively less competitive. This situation has been blamed for the loss of U.S. manufacturing jobs.

The exchange rate system is also tied to the central bank's monetary policy. The PBOC buys Dollars with RMB to keep the value of the Yuan closely linked to the Dollar. In order to prevent inflation, the PBOC must sterilize Dollar purchases by issuing bonds which counteract the money supply increase. If the current situation continues, the amount of outstanding bonds will grow to the point where it will begin to crowd out business investment. This will lead to greater financial market inefficiencies which will limit the return on investment throughout the country. The PBOC currently relies more on reserve requirements than selling bonds to reduce the domestic money supply not out of concern for the crowding out effect, but because interest paid on deposits with the central bank are much lower than interest payments on government bonds.

A country's central bank can apply three types of exchange rate regimes: floating, fixed, or managed float also called a dirty float. Under a floating exchange regime such as the U.S. Dollar, the value of the currency is determined by demand and supply. Capital inflows and exports create foreign demand for currency in order to purchase American goods and investments causing the Dollar to appreciate. Capital outflows and imports reduce demand as Americans sell Dollars to buy foreign products causing the Dollar to depreciate. Under a fixed regime such as the Saudi riyal, the central bank uses its foreign currency reserves to support the riyal when supply exceeds demand and increases the money supply when demand exceeds supply. The fixed system is most effective if the country limits capital flows and has plenty of foreign currency reserves however, the central bank cannot control inflation. The managed float combines these strategies in order to limit volatility.

China's managed float of the Yuan shares more characteristics with a fixed exchange rate than a floating system due to the strict limitations on how much movement is allowed. "Under flexible exchange rate regimes, relative prices can adjust instantly through changes in the nominal exchange rate; whereas under fixed exchange rate 
regimes, relative prices can adjust only at the speed which is permitted by price stickiness..."21 This process has less of an impact on China's economy since there is far less consumption relative to the percentage of output devoted to exports. ${ }^{22}$ Chinese prices are also relatively less sticky due to the common practice of negotiating prices in the market as opposed to U.S. firms which typically have fixed prices and higher menu costs. Chinese businesses often negotiate deals based on relationship rather than adhere to a rigid price schedule. This allows businesses to quickly adapt to the current market environment.

A fixed exchange rate system also has its benefits. China's fixed exchange rate is credited with providing stability during the Asian financial crisis. ${ }^{23}$ A shock such as the Asian financial crisis causes businesses to delay expansion plans and consumers to reduce consumption which reduces money demand. The PBOC sells foreign currency and decreases the money supply. Real output remains constant and the exchange rate is fixed. If terms of trade deteriorate, the central bank sells foreign currency and decreases the money supply causing an additional decrease in real output. This allows China to protect the economy better from small shocks but very large shocks can negatively impact the economy due to the cumulative effects of the reduction in exports and reduction of output.

\section{WTO Accession Terms}

Negotiations for China to enter the WTO lasted 15 years. In 2001, despite many high profile issues, the U.S. has only filed one case against China which involved car parts. ${ }^{24}$ Due to the country's rapid development, China has had difficulty building the regulatory framework necessary to oversee private business.

China has a weak history of enforcing international working conditions and environmental standards. This allows businesses to reduce costs more than foreign competitors. Government involvement in private business allows for greater influence through subsidies and bank loans. Other trade practices such as selling at less than fair value (commonly called dumping) reflect China's struggle to institutionalize international trade standards. Some of the more recent trade disputes are:

- $\quad$ Imposing 20\% tariffs on high-gloss paper products effective March 30, $2007^{25}$

- $\quad$ Requiring export licenses for military related items to China effective January $13,2006^{26}$

- $\quad$ Progressive quotas in order to control the flood of textiles allowed under the China WTO Textile Safeguard through $2008^{27}$

- $\quad$ The U.S. Trade Representative placed China on the Special 301 Priority Watch List for IP protection ${ }^{28}$

As part of the accession terms, China agreed to "grant full trade and distribution rights to foreign enterprises. ${ }^{, 29}$ Foreign firms are also required to be treated in the same manner as domestic firms. This section also prohibits the use of dual pricing systems. Local businesses continue to utilize price discrimination due to a lack of regulations and difficulties in enforcement. Currently, the information ministry requires foreign financial information companies to distribute their services through the Xinhua news agency. ${ }^{30}$ China requires foreign firms in certain industries to form joint ventures with domestic firms in order to gain access to the Chinese markets. Chinese firms benefit from management and technology transfer while foreign firms can quickly access the market without developing their own subsidiaries.

While Intellectual Property (IP) rights protection has been controversial with regard to China, adoption of western regulations will not completely solve the problem. China has difficulties enforcing the rule of law in various

\footnotetext{
${ }^{21}$ Chia and Alba, 41

${ }^{22}$ The Economist Country Briefing

${ }^{23}$ Morrison, 6

${ }^{24}$ The Economist, 7 December 2006

${ }^{25}$ The Economist, 2 April 2007

${ }^{26}$ Lum and Nanto, 3

${ }^{27}$ Lum and Nanto, 3

${ }^{28}$ Morrison, 1

${ }^{29}$ Morrison, 9

${ }^{30}$ The Wall Street Journal, 11 September 2006
} 
domains of society and more legislation will not change the behavior of Chinese individuals, businesses, or local governments. Oftentimes, proximity to Beijing combined with local business influence is what determines how local governments enforce IP regulations. This is tied directly to China's system for political advancement. Local government officials are evaluated by the economic development of their region. As a result, politicians are eager to promote foreign direct investment and are not motivated to enforce regulations which may restrict Chinese businesses from profiting from foreign intellectual property.

China is in a unique position to affect world technology standards by developing domestic standards with the confidence that foreign firms will follow in order to access China's large market. One example comes from the 2003 case of Wi-Fi encryption standards. China had proposed a new set of wireless encryption algorithms that differed substantially from the internationally recognized standards. This would create additional costs for foreign firms by forcing them to manufacture a different type of device to sell to the Chinese market as one option while the other option would violate IP rights by requiring foreign firms to provide technical specifications to potential competitors. China claims the new standards are exempt from WTO regulations because they pertain to national security. This issue was never fully explored because China has postponed the adoption of the standards indefinitely and the United States has not brought the issue before the WTO.

When China joined the WTO, it announced its intention to sign the Government Procurement Agreement which would require open bids on software contracts with the Chinese government. To date, China has not signed the agreement therefore a Linux based e-government initiative does not violate current WTO obligations. In 2002, government procurement increased from 0.04 percent of GDP in 1998 to 9.64 percent. ${ }^{31}$ This growth has allowed the government to use procurement as a means of setting policy.

Suttmeier and Yao (2004) describe China's technology policies as Neo Techno-Nationalism. They characterize China's policies as using globalization to promote national interests utilizing both private and government partnership to lead innovation. This will lead to either cooperation or conflict with foreign firms and is situational dependent. Chinese policy makers realize that domestic firms are not mature enough to directly compete with multinational corporations. An alternative to direct competition is the promotion of new standards which can be licensed or used as leverage for promoting partnerships that include technology transfers. While government policies and procurement are insufficient to accomplish this on their own, the promise of access to the Chinese market as well as the competition of multinationals can provide the power necessary to challenge western technology standards.

Shen (2005) suggests that China simply faces a decision between a weak or strong IP regime but that the decision is complicated by economic considerations. Some theorists in developed countries argue that a strong IP regime promotes foreign direct investment and encourages domestic development. Shen argues that a strong IP regime only benefits established multinationals because of the costs associated with research and development as well as the legal costs to combat the violation of IP protection. While this may be true in a free market economy with strong IP enforcement; this is clearly not the situation in China. Whether or not China accepts strong IP regulation is less important than enforcement and the strength of the judicial system. The example of the "four little Asian tigers" shows that economic growth may develop in weak IP environments by allowing technology transfers to occur from foreign multinationals to domestic firms. Developing countries have an interest in maintaining loose IP regulations and enforcement in order to enhance economic growth.

The main obstacle to developing an effective regulatory environment in China is the regional government promotion system. Local governmental leaders are evaluated primarily based on the economic growth of their cities or provinces leading to a strong incentive for regional governments to allow businesses to cut corners in order to stay competitive and attract new firms by promising a favorable business environment. Similar conflicts of interest exist in democratic systems through campaign financing but the lack of direct voting and freedom of the press makes the situation in China difficult to change.

\footnotetext{
${ }^{31}$ Suttmeier and Yao, 35
} 


\section{LONG TERM IMPACT}

Over the past several years, the U.S. - China trade relationship has become of increasing concern. Nearly every labor intensive industry has attributed their woes to what in the U.S. is perceived as unbalanced trade with China. If the current trade with China is considered unbalanced, what is the impact to the American economy? This question can be addressed in two ways.

First, does the reliance on a foreign market for increasing amounts of goods affect the ability of the economy to respond to changes in resource prices and demand fluctuations? While transportation costs have declined substantially, the complexity of supply chain management, communication, and transportation time remain barriers to a responsive market. Additionally, multinational finance generally creates risk which smaller firms may find either too difficult to manage due to the country's financial development or too costly to hedge with financial instruments. Many Chinese firms face these problems due to China's developing banking system and the relatively smaller size of Chinese firms as compared to older, western multinational corporations.

If a substantial amount of goods are produced abroad, consumers will not be able to substitute domestic goods as foreign goods become more expensive. The price volatility caused by foreign firms could lead to consumption volatility in the domestic market. Persistent volatility in the American economy would eventually cause foreign investors to reduce capital inflows to the U.S. unless interest rates increase. If the U.S. cannot attract enough foreign capital, the current account must decrease by the same amount as the decrease in capital inflows. Balance would only be restored by much higher interest rates and less foreign goods causing prices on domestic goods to dramatically increase.

The second approach to the trade balance problem is to start at the end and work our way backwards. First, we find a sustainable current account balance; then we calculate the exchange rate adjustment needed given the U.S. current net debt position. In order to find a sustainable current account balance, we must understand the cause. The current account deficit is explained by faster consumption growth relative to domestic production and consumer preference for foreign goods over domestic goods. The financial account surplus is simply foreign demand for U.S. equities and bonds which enables the current account deficit to continue. In 2005, Blanchard, Giavazzi, and Sa developed a unique and straight forward model that assumes imperfect substitution between foreign and domestic goods and financial instruments. The sustainability section will discuss this model in more detail.

\section{Volatility}

The model discussed by Kose, Prasad, and Terrones in their 2003 IMF staff paper examines whether trade flows impact U.S. consumption and government expenditures. Trade flows are represented by the trade openness index defined as the sum of a country's imports and exports divided by output. Volatility is derived from the standard deviation of the percentage change in consumption and government expenditures divided by income. The income variable is used to account for prolonged periods of economic growth or recession and the resulting standard deviation measures volatility due to business cycle fluctuations. Kose et al. found that there was a correlation between trade flows and macroeconomic volatility, but financial integration explained the degree to which an economy would be affected.

The U.S. clearly has a well developed financial system, however many of its trading partners do not. This model will measure whether the results of Kose et al. apply to the U.S. over the period since most favored nation trading status was granted to China. All data was obtained from the economic research database at the St. Louis Federal Reserve Bank website. ${ }^{32}$ A rolling five period window was used to calculate the standard deviation of consumption and government spending growth in order to follow the IMF paper.

\footnotetext{
${ }^{32}$ http://research.stlouisfed.org/fred2
} 


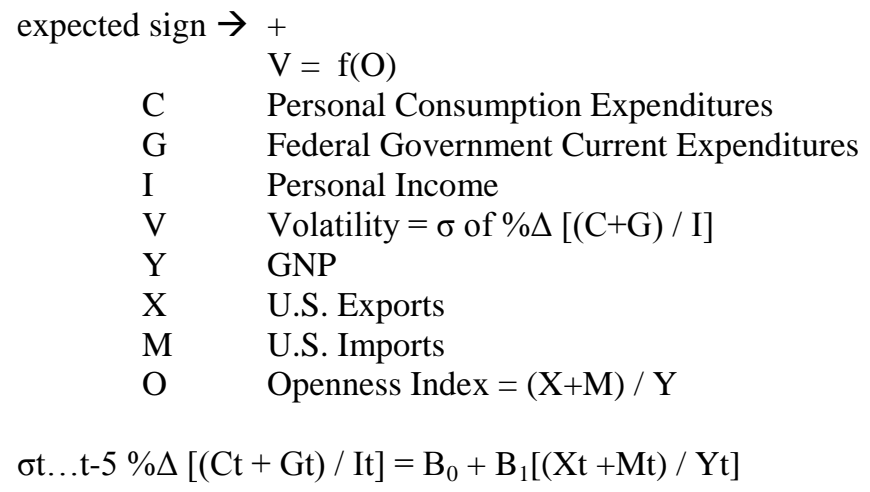

This regression yields the following estimated model:

Volatility $=0.011030-0.053024$ Openness Index

Standard Errors $\rightarrow(0.003483)(0.048716)$

The complete regression output can be found in Appendix A. While the results indicate that the openness index cannot explain volatility with confidence, the negative openness index elasticity leads us to believe that trade integration likely has not caused volatility in consumption and government spending growth in the U.S. from 1980 through 2006. Another regression separating the U.S. openness index into individual country trade flows also yielded statistically insignificant results. While serial correlation was a concern, the generalized least squares model was applied using the AR(1) method. The resulting Durbin-Watson statistic allows us not to reject the hypothesis of no serial correlation in the two tailed test. China's less developed financial system may impact on U.S. economic volatility, but the effect is either negated by other U.S. trade partners or is not significant.

\section{Sustainability}

If there is no threat of volatility from increased trade, is the current trade relationship sustainable? This question must be addressed in terms of the time necessary to reach equilibrium. It is reasonable to assume that in the long run China will float the Yuan and implement liberal economic policies similar to those of the developed world. A floating exchange rate combined with a drastic reduction in tariffs and subsidies would allow the trade deficit to move towards equilibrium over the long term but the conditions during the adjustment period may be unacceptable without government intervention.

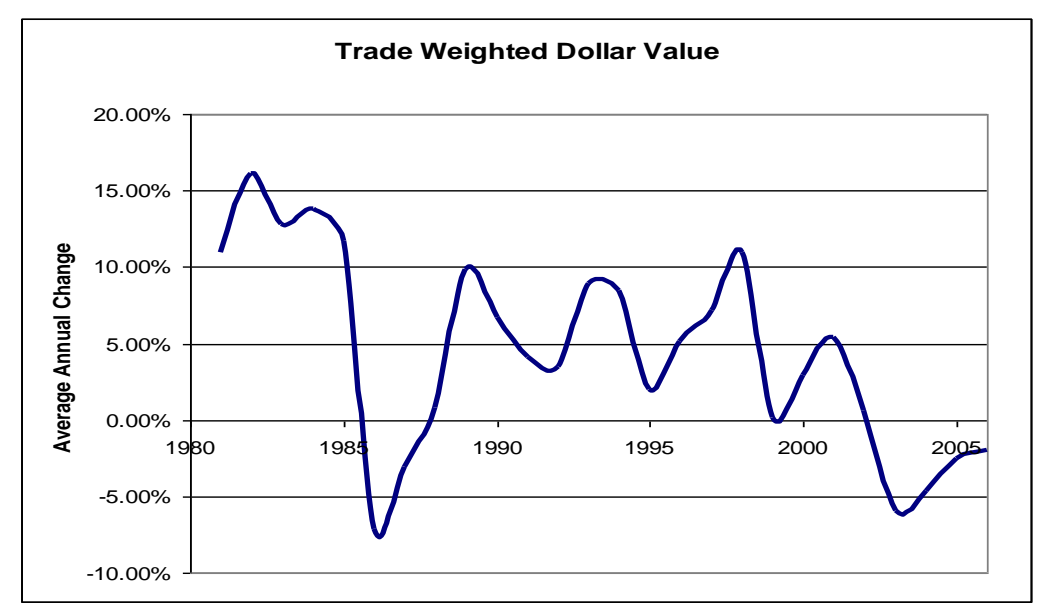


In a country with a large trade surplus such as China, other countries must pay for these exports in Yuan. This causes the demand for Yuan to increase relative to other currencies resulting in appreciation. Under a floating exchange rate system, the higher valued Yuan reduces foreign demand for Chinese exports ultimately reducing China's trade surplus. China's managed float limits the amount of appreciation and the ability of exchange rates to bring trade flows into equilibrium. The resulting undervalued Yuan permits China to continue to run a current account surplus. When the Yuan is permitted to float, we can expect the Dollar to depreciate relative to the Yuan due to the demand for Yuan to pay for Chinese exports. The increase in the relative price of Chinese exports would cause a shift in demand back towards domestic goods reducing the Chinese surplus. The speed at which this adjustment occurs depends on whether foreign demand for U.S. assets continues to increase. If demand increases as it has in recent years, the eventual Dollar depreciation will be delayed.

The model proposed by the 2005 Brookings paper explains the relationship between the current account, exchange rate, and the national debt. This model can only be properly applied to the U.S. because it assumes that assets held by foreign investors are denominated in Dollars and are unaffected by a depreciation of the Dollar. A change in the exchange rate affects both the trade balance and the value of assets resulting in changes to the financial account and the current account. U.S. debt is denominated in Dollars so a depreciation of the Dollar lowers the value of interest payments resulting in a reduction of the debt. The depreciation also reduces the cost of domestic goods relative to foreign goods causing a reduction in the trade deficit. The dual effects of a change in the exchange rate are described by the Marshall-Lerner relation and the current account balance relation. ${ }^{33}$

$$
\begin{gathered}
\Delta \mathrm{D} / \text { Exports }=\left[\pi_{\text {imports }}-\pi_{\text {exports }}-1\right]^{* \% \Delta \mathrm{E}} \\
\Delta \mathrm{F} / \mathrm{Y}=(1-\alpha)(1+\mathrm{r})[(\mathrm{X}-\mathrm{F}) / \mathrm{Y}](\% \Delta \mathrm{E})
\end{gathered}
$$

F $\quad$ Net debt position of the U.S.

Y U.S. Gross Domestic Product

$\alpha \quad$ Percentage of U.S. wealth invested in U.S. assets

$\mathrm{r} \quad$ World interest rate

X Total U.S. assets

E Exchange rate

$\pi \quad$ Elasticity of U.S. imports and exports

D U.S. trade deficit as a percentage of GDP

The Marshall-Lerner relation explains the degree to which the exchange rate impacts the trade balance. Based on a review of current literature on the subject, Blanchard, Giavazzi, and Sa estimate 0.67 as the value for the term in brackets which combines the import and export elasticities. Given a $1 \%$ reduction in the trade deficit and an exports-to-GDP ratio of $10 \%$, the 0.67 estimate results in a depreciation of $14.93 \%$. $(1 \% / 10 \% / 0.67=14.93 \%)$

The second equation explains the amount that interest payments on the national debt will be decreased due to valuation effects. Blanchard et al. assumed the world interest rate to be about $4 \%$ in 2003 . This estimate seems reasonable and does not seem likely to change significantly in the short term. Data for the remaining variables was obtained from the economic research database at the St. Louis Federal Reserve Bank ${ }^{34}$ and the Bureau of Economic Analysis ${ }^{35}$ utilizing the most recent data available for all variables from 2005. The Dollar exchange rate is the U.S. trade weighted index published by the Federal Reserve.

\footnotetext{
${ }^{33}$ Blanchard, Giavazzi, and Sa, 8

${ }^{34}$ http://research.stlouisfed.org/fred2

$35 \underline{\mathrm{http}: / / \text { www.bea.gov/international/index.htm }}$
} 


\begin{tabular}{|l|l|l|}
\hline Variable & Description & 2005 Value \\
\hline $\mathrm{F}$ & Net debt position of the U.S. & $\$ 3,273$ billion \\
\hline$\Delta \mathrm{F} / \mathrm{Y}$ & Change in Net Debt as a percentage of GDP & $1.93 \%$ \\
\hline $\mathrm{Y}$ & U.S. Gross Domestic Product & $\$ 12,456$ billion \\
\hline $\mathrm{A}$ & Percentage of U.S. wealth invested in U.S. assets & $72 \%$ \\
\hline $\mathrm{R}$ & World interest rate & $4 \%$ \\
\hline $\mathrm{X}$ & Total U.S. assets & $\$ 42,076$ billion \\
\hline Exports & Exports as a percentage of GDP & $14.05 \%$ \\
\hline$\left[\pi_{\text {imports }}-\pi_{\text {exports }}-1\right]$ & Elasticity of U.S. imports and exports & 0.67 \\
\hline$\Delta \mathrm{D}$ & Change in the U.S. trade deficit as a percentage of GDP & $0.67 \%$ \\
\hline
\end{tabular}

By combining the two equations and solving for the exchange rate, we can discover how the current account deficit affects the exchange rate at equilibrium. Blanchard et al. adds the effects of trade to valuation effects to arrive at the change in the debt to GDP ratio.

$\Delta \mathrm{D}+\mathrm{r}(\Delta \mathrm{F} / \mathrm{Y})=\operatorname{total} \Delta \mathrm{F} / \mathrm{Y}$

Substituting the two equations we arrive at the following combined equation:

$\left[\pi_{\text {imports }}-\pi_{\text {exports }}-1\right](\% \Delta \mathrm{E})($ Exports $)+\mathrm{r}[(1-\alpha)(1+\mathrm{r})[(\mathrm{X}-\mathrm{F}) / \mathrm{Y}](\% \Delta \mathrm{E})]=$ total $\Delta \mathrm{F} / \mathrm{Y}$

If we input the variable values from 2005, we get:

$0.67(\% \Delta \mathrm{E}) 14.05 \%+4 \%[(1-0.72) 1.04(3.115)(\% \Delta \mathrm{E})]=1.93 \%$

Simplified:

$0.0941(\% \Delta \mathrm{E})+0.0362(\% \Delta \mathrm{E})=0.0193$

Solving for the change in exchange rate:

$\% \Delta \mathrm{E}=14.98 \%$

This number represents the amount that the Dollar would need to appreciate against the trade weighted index in order to compensate for the debt accumulated over 2005. The actual exchange rate change in 2005 was a depreciation of $2.56 \%$. This results in a $17.54 \%$ discrepancy. How can this discrepancy be explained?

One way to explain this discrepancy is the Chinese central bank's purchase of U.S. treasury bonds at low interest rates combined with the managed float of the Yuan. This allows the U.S. to keep interest rates low because it does not need to attract foreign investors with higher rates. While this process is certainly in play, it does not completely explain the magnitude of the discrepancy. Given the efficiency of foreign exchange markets, it is more likely that the value of the Dollar incorporates information of the longer term trend discussed below.

The U.S. cannot continue to accumulate debt indefinitely due to the rising interest payments therefore, it would be useful to determine the value of the Dollar once the growth of the U.S. net debt position approaches zero. While a free floating Yuan is still several years away, let's assume that the slow appreciation of the Yuan eventually stops the growth of the U.S. current account deficit. At 2005 levels for all variables, the Dollar would need to depreciate approximately $3 \%$ per year in order to keep interest rates constant. Since this situation is not likely to occur for several years, GDP growth must be taken into account. Blanchard, Giavazzi, and Sa (2005) propose that a sustainable current account deficit can be calculated as $\mathrm{g}(\mathrm{F} / \mathrm{Y})$ where $\mathrm{g}$ is the nominal GDP growth rate. ${ }^{36}$ Assuming that the ratio of net debt to GDP can be sustained at $26 \%$ and nominal GDP growth averages about $3 \%$ per year, the

\footnotetext{
${ }^{36}$ Blanchard, Giavazzi, and Sa, 21
} 
U.S. can run a deficit of $0.79 \%$ of GDP without increasing the debt to GDP ratio (3\%*26\%). Keeping in mind that the current account deficit was $6.35 \%$ of GDP in 2005 , it would need to adjust by $5.56 \%(6.35 \%-0.79 \%)$.

Returning to the Marshall-Lerner relation and the current account balance relation, a $10 \%$ Dollar depreciation results in a $0.94 \%$ current account deficit decrease due to the trade balance effect and a $0.36 \%$ decrease from valuation effects. Multiplying the adjustment of $5.56 \%$ by the depreciation per unit of adjustment (10\% / 1.3\%) gives us the required Dollar depreciation of $42.77 \%$ necessary to reach a sustainable current account deficit. While this number seems unrealistic, it is important to remember the assumptions which underlie the theory. First, it assumes floating exchange rates and constant interest rates. Second, it assumes a single period snap to equilibrium which is unrealistic. The adjustment period will likely take many years and interest rates will need to rise to attract additional foreign capital once the Chinese central bank reduces its supply of Dollars. In the long run, we can expect the Dollar to continue to depreciate until the current account reaches a sustainable level.

\section{CONCLUSION}

Volatility caused by greater economic integration and business cycle synchronization has not been a problem for the U.S.-China trade relationship, but the current account deficit cannot be sustained indefinitely. With a 43\% Dollar depreciation necessary to reach equilibrium, should the U.S. implement policies which ease the transition to a sustainable trade policy or simply allow the market to adjust? As discussed earlier, the severity of the adjustment will depend on the time over which the adjustment takes place. If trade barriers were used to control the adjustment period China may not necessarily be the appropriate target.

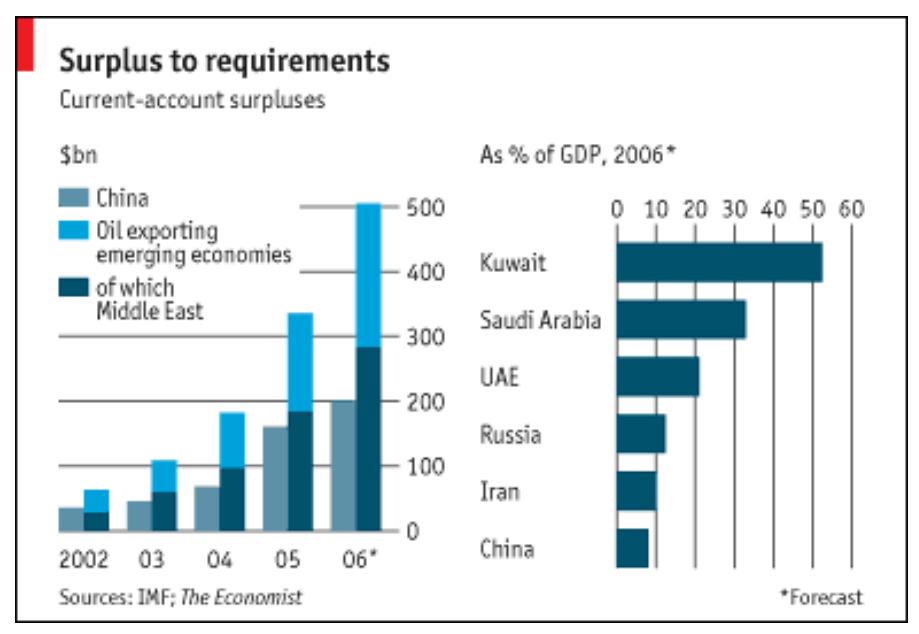

The members of the Gulf Cooperation Council (GCC), which consists of the countries of Saudi Arabia, United Arab Emirates, Kuwait, Bahrain, Oman and Qatar, peg their currencies to the Dollar while running a trade surplus of about $\$ 500$ billion in $2006 .{ }^{37}$ Compared with China's $\$ 200$ billion, the GCC has a much greater impact on the U.S. current account balance. The Dollars accumulated are not reported because they are deposited into investment funds and oil-stabilization funds rather than central bank reserves. The GCC surplus cannot be easily handled through trade policies since the U.S. depends on the oil exports of these countries for its economic growth and placing pressure on the GCC members is also not an alternative since the Dollar peg is also used to prepare the countries to move to a common currency by 2010 .

A better method for managing U.S.-China trade is through policies that target the domestic savings rate in both countries. China's high savings rate is largely a result of a lack of social programs such as health insurance and retirement plans. About 14 percent of Chinese have health insurance and a pension plan. The central and local

\footnotetext{
${ }^{37}$ The Economist, 7 December 2006
} 
governments spend only 4 percent of GDP on education, health, retirement, and social security. ${ }^{38}$ If China's savings rate could be reduced, it could develop its domestic economy to the point where growth no longer depends on exports. By creating a social safety net, the Chinese government could provide greater political stability while allowing the Yuan to float and increasing the purchasing power of Chinese citizens.

The current tax treatments of Individual Retirement Accounts (IRA's), 401k plans, and other retirement contribution plans are a good start, but the U.S. needs to do more to encourage savings. Barring any catastrophic tax increases, social security benefits must decrease in order to serve the aging generation of baby boomers. Americans will save more as benefits decline, but the use of credit needs to be more regulated in order to prevent consumers from taking on more debt than they can afford. This problem has recently surfaced in the sub-prime lending market where low interest rates and rapid housing appreciation led to banks granting variable rate mortgages to people with insufficient income and little to no equity to prevent foreclosure when interest rates increase and real estate prices decrease. As financial integration increases, volatility in global capital markets may prompt other countries to maintain capital controls rather than allow U.S. debt problems to influence global economic growth. In this scenario, the U.S. should be more concerned with reducing exported volatility before foreigners lose faith in the stability of American institutions.

\section{BIBLIOGRAPHY}

1. Bernanke, Ben S. (2006) "The Chinese Economy: Progress and Challenges", Remarks at the Chinese Academy of Social Sciences, Beijing, China, 15 December 2006.

2. Blanchard, Olivier, Giavazzi, Francesco, Sa, Filipa, Bernanke, Ben S., and Rey, Helene (2005)

"International Investors, the U.S. Current Account and the Dollar" Brookings Papers on Economic Activity, No.1, 1-65.

3. Browne, Andrew, (2006) "Beijing Is Cracking Down On Foreign-Media Access Stricter Curbs Give Xinhua More Control Over Financial News", The Wall Street Journal, 11 September 2006, A2.

4. Chia, Wai-Mun and Alba, Joseph D., (2006) "Terms-of-Trade Shocks and Exchange Rate Regimes in a Small Open Economy", The Economic Record, Vol.82, 41-53.

5. Gerber, James, (2005) International Economics. (Addison-Wesley: Boston)

6. Kose, M. Ayhan, Prasad, Eswar S., and Terrones, Marco E., (2003) "How Does Globalization Affect the Synchronization of Business Cycles", The American Economic Review, Vol.93: Iss.2, 57-62.

7. Kose, M. Ayhan, Prasad, Eswar S., and Terrones, Marco E., (2003) "Financial Integration and Macroeconomic Volatility”, IMF Staff Papers, Vol.50, 119-142.

8. Kraay, Aart and Ventura, Jaume, (2002) “Trade Integration and Risk Sharing”, European Economic Review, Vol.46, 1023-1048.

9. Krugman, Paul, (1989) "The J-Curve, the Fire Sale, and the Hard Landing" The American Economic Review, Vol.79: No.2, 31-35.

10. Lum, Thomas and Nanto, Dick K., (2006) China's Trade with the United States and the World. (Congressional Research Service: Washington D.C.)

11. Mann, Catherine L., (2002) "Perspectives on the U.S. Current Account Deficit and Sustainability", The Journal of Economic Perspectives, Vol.16: No.3, 131-152.

12. Morrison, Wayne M., (2005) China-U.S. Trade Issues. (Congressional Research Service: Washington D.C.)

13. Obstfeld, Maurice and Rogoff, Kenneth S., (2005) "Global Current Account Imbalances and Exchange Rate Adjustments", Brookings Papers on Economic Activity, No.1, 67-146.

14. Razin, Assaf, et al. (2003) "Trade Openness, Investment Instability, and Terms-of-Trade Volatility", Journal of International Economics, Vol.61: Iss.2, 285-306.

15. Ramey, Garey and Ramey, Valerie A., (1995) "Cross-Country Evidence on the Link Between Volatility and Growth", The American Economic Review, Vol.85: No.5, 1138-1151.

16. Shen, Xiaobai, (2005) "Developing Countries Perspectives on Software: Intellectual Property and Open Source - A Case Study of Microsoft and Linux in China", International Journal of IT Standards \& Standardization Research, No. 1, 21-43.

\footnotetext{
${ }^{38}$ Bernanke (2006)
} 
17. Suttmeier, Richard P. and Yao, Xiangkui, (2004) “China's Post-WTO Technology Policy: Standards, Software, and the Changing Nature of Techno-Nationalism”, National Bureau of Asian Research, May 2004, No. 7.

18. The Economist, (2006) "Paulson's Party", December 7, 2006

19. The Economist, (2006) "PetroDollar Peg", December 7, 2006

20. The Economist, (2007) "Trouble with Trade", April 2, 2007

21. The Economist, (2006) "Who Wants to be a Trillionaire?", October 28, 2006

22. Young, Leslie and Anderson, James E., (1982) "Risk Aversion and Optimal Trade Restrictions", The Review of Economic Studies, Vol.49: No.2, 291-305.

\section{APPENDIX A}

Dependent Variable: CGPI_VOL

Method: Least Squares

Date: 04/02/07 Time: 16:31

Sample: 1980:1 2006:2

Included observations: 106

Convergence achieved after 5 iterations

\begin{tabular}{|c|c|c|c|c|}
\hline Variable & Coefficient & Std. Error & t-Statistic & Prob. \\
\hline $\begin{array}{l}\mathrm{C} \\
\text { OPENINDEX } \\
\text { AR(1) }\end{array}$ & $\begin{array}{l}0.011030 \\
-0.053024 \\
0.897401 \\
\end{array}$ & $\begin{array}{l}0.003483 \\
0.048716 \\
0.045240 \\
\end{array}$ & $\begin{array}{l}3.166822 \\
-1.088428 \\
19.83659 \\
\end{array}$ & $\begin{array}{l}0.0020 \\
0.2789 \\
0.0000 \\
\end{array}$ \\
\hline $\begin{array}{l}\text { R-squared } \\
\text { Adjusted R-squared } \\
\text { S.E. of regression } \\
\text { Sum squared resid } \\
\text { Log likelihood } \\
\text { Durbin-Watson stat } \\
\text { Inverted AR Roots }\end{array}$ & $\begin{array}{c}0.811739 \\
0.808083 \\
0.001036 \\
0.000111 \\
579.5806 \\
1.850270 \\
.90\end{array}$ & \multicolumn{2}{|c|}{$\begin{array}{l}\text { Mean dependent va } \\
\text { S.D. dependent var } \\
\text { Akaike info criterio } \\
\text { Schwarz criterion } \\
\text { F-statistic } \\
\text { Prob(F-statistic) }\end{array}$} & $\begin{array}{l}0.006989 \\
0.002365 \\
-10.87888 \\
-10.80350 \\
222.0558 \\
0.000000\end{array}$ \\
\hline
\end{tabular}


NOTES 